\title{
GENDER EQUITY IN AUSTRALIAN HEALTH LEADERSHIP
}

Amanda Cohn', Mya Cubitt2, Anita Goh³, Allison Hempenstall4, Rebekah Hoffman5, Christine Laib, Jane Munro7, Carly Silvester8, Clare Skinner', Deborah Verran ${ }^{10}$, Jordan Walteril
1. Gateway Health VIC, Australia; University of New South Wales, NSW, Australia
2. The Royal Melbourne Hospital, VIC, Australia; The University of Melbourne, VIC, Australia
3. National Ageing Research Institute, VIC, Australia; The University of Melbourne, VIC, Australia
4. James Cook University, Queensland, Australia; Australian Institute of Tropical Health and Medicine, QLD, Australia
5. University of Wollongong, NSW, Australia
6. The Queen Elizabeth Hospital, SA, Australia
7. The Royal Melbourne Hospital, VIC, Australia; The University of Melbourne, VIC, Australia
8. Noosa Hospital, QLD, Australia; University of Queensland, QLD, Australia
9. Hornsby Ku-ring-gai Hospital, NSW, Australia
10. Ramsay HealthCare, NSW, Australia
11. Barwon Health, VIC, Australia

Correspondence: ahempenstall7@gmail.com

\section{ABSTRACT}

\section{OBJECTIVE}

To ascertain the gender distribution across public health boards in Australia.

\section{DESIGN \& SETTING}

Analysis of data and information obtained from a cross sectional audit of online publicly listed health boards within Australia from October to December 2019.

\section{RESULTS}

The majority of public health boards have close to equal representation of women as board members however women are underrepresented in Chair roles. Victoria has significantly more women on health boards, whereas New South Wales has significantly less women on health boards and in Chair positions.

\section{CONCLUSIONS}

Further efforts are required to drive gender equity in senior leadership roles in public health boards across Australia.

\section{KEYWORDS}

Gender equity, health leadership 
Gender parity in health leadership positions remains a challenge. Women comprise only $12.5 \%$ of hospital chief executive officers, $28 \%$ of medical school deans and $29 \%$ of medical college board members. [1] These disparities are even greater for Aboriginal and Torres Strait Islander women, women of colour, women from other minority groups and women with disabilities. [2] It is well established

that gender equity in health leadership is positively correlated with improved organisational and societal outcomes. [3,4] Furthermore, evidence is emerging that the disparity in leadership negatively affects health outcomes for women and children worldwide.[5]

Barriers to gender equity in health leadership include women's perceived capacity, capability and credibility. $[1,6]$ Women frequently report workplace gender, pregnancy, and carer-related discrimination. [6] The often disproportionate burden of family responsibilities that women bear can also impede career advancement. [6] Women also often perceive themselves to be less capable candidates for leadership positions and are uncomfortable with self-promotion.[7] A series of hypothetical scenarios found that women candidates are more likely to be appointed to a leadership position when the position was considered risky and there is an increased risk of failure. [8] Systemic gender biases ingrained in organisational cultures promote masculine leadership values, alienating women from these positions.[1] Researchers at Yale University used different genders on two identical job applications to explore bias in the job market. They found that regardless of selectors gender, most people evaluated 'John' as significantly more competent and more hireable. 'Jennifer' was offered a $12 \%$ lower salary and less mentorship.[9]

In order to increase the representation of women in senior healthcare leadership, effective strategies to promote gender equity in health leadership can include mentorship and sponsorship, leadership education, and establishing targets or quotas for women in leadership positions.[6] A minimum threshold for women positions is necessary to reduce the negative impacts of being underrepresented. [10] In 2019, the Australian Medical Association of Victoria changed its constitution to include a $40 \%$ gender quota for its board.[1 1] Male allies are also vital in supporting genderinclusive workplaces.[12,13] The aim of this audit was to review the gender distribution across public health boards

in Australia in order to assess whether gender parity is close to being achieved.

\section{METHODS}

Australian public hospital and health service websites were accessed during the period Monday 21st October to Wednesday 3rd December 2019. The gender of each board member (including the Chair) was collated. As no specific information was available about which gender each member chooses to identify with, gender status was assumed on the basis of photographic appearance, name and pronoun/title used in biographic information available online. No board spills or reappointments took place during the period of the study. No information was available online regarding hospital or health service boards in Tasmania and the Australian Capital Territory, so senior health managers in both of these jurisdictions were contacted by telephone. They reported that no boards, or equivalent entities, were currently in operation. These jurisdictions were therefore excluded from analysis. Descriptive statistics (calculated in Microsoft Excel) were used to report gender proportions for board members and board Chairs. Proportions are compared to statistically expected proportions of $50 \%$ (for gender parity) using Pearson's chi square or Fisher's exact test where expected cell counts were below five. Ethics approval was not required for this study.

\section{RESULTS}

The numbers of board members and board Chairs by gender and by state are shown in Table One. Nationally, $53 \%$ of board members were women and this did not differ significantly from the $50 \%$ expected $(p=0.06)$. The proportion of women board members ranged from $38 \%$ $(p=0.03)$ in New South Wales (NSW) to $59 \%(p=0.27)$ in the Northern Territory (NT). Victoria was the only jurisdiction where women made up the majority of board members with statistical significance $(55 \%, p=0.04)$. Nationally, $45 \%$ of board Chairs were women and this did not differ significantly from the $50 \%$ expected by chance $(p=0.19)$. The proportion of women board Chairs ranged from $13 \%$ $(p=0.04)$ in NSW to $67 \%(p=0.83)$ in the NT. NSW was the only jurisdiction where the representation of women was significantly less for both board members (38\%; $p=0.03$ ) and board Chair roles (13\%; $p=0.04$ ). 
TABLE 1: BOARD MEMBERS AND BOARD CHAIRS BY GENDER AND BY STATE ACROSS AUSTRALIA IN 2019. P VALUE CALCULATED FROM CHI SQUARE EXCEPT WHERE NOTED. *FISHER'S EXACT TEST DUE TO LOW EXPECTED CELL COUNTS

\begin{tabular}{|c|c|c|c|c|c|c|c|c|}
\hline STATE & $\begin{array}{l}\text { NUMBER } \\
\text { OF } \\
\text { WOMEN } \\
\text { BOARD } \\
\text { MEMBERS }\end{array}$ & $\begin{array}{l}\text { NUMBER } \\
\text { OF MEN } \\
\text { BOARD } \\
\text { MEMBERS }\end{array}$ & $\begin{array}{l}\text { WOMEN } \\
\%\end{array}$ & $\begin{array}{l}\text { P } \\
\text { VALUE }\end{array}$ & $\begin{array}{l}\text { NUMBER } \\
\text { OF } \\
\text { WOMEN } \\
\text { BOARD } \\
\text { CHAIRS }\end{array}$ & $\begin{array}{l}\text { NUMBER } \\
\text { OF MEN } \\
\text { BOARD } \\
\text { CHAIRS }\end{array}$ & $\begin{array}{l}\text { WOMEN } \\
\%\end{array}$ & $\begin{array}{l}\text { P } \\
\text { VALUE }\end{array}$ \\
\hline $\begin{array}{l}\text { NEW SOUTH } \\
\text { WALES }\end{array}$ & 63 & 102 & $38 \%$ & 0.03 & 2 & 13 & $13 \%$ & 0.04 \\
\hline $\begin{array}{l}\text { NORTHERN } \\
\text { TERRITORY }\end{array}$ & 41 & 28 & $59 \%$ & 0.27 & 2 & 1 & $67 \%$ & $0.83^{*}$ \\
\hline QUEENSLAND & 74 & 66 & $53 \%$ & 0.63 & 5 & 11 & $31 \%$ & 0.29 \\
\hline $\begin{array}{l}\text { SOUTH } \\
\text { AUSTRALIA }\end{array}$ & 37 & 32 & $54 \%$ & 0.67 & 3 & 7 & $30 \%$ & $0.39 *$ \\
\hline VICTORIA & 403 & 324 & $55 \%$ & 0.04 & 45 & 36 & $56 \%$ & 0.48 \\
\hline $\begin{array}{l}\text { WESTERN } \\
\text { AUSTRALIA }\end{array}$ & 27 & 21 & $56 \%$ & 0.61 & 1 & 4 & $20 \%$ & $0.36^{*}$ \\
\hline TOTAL & 645 & 573 & $53 \%$ & 0.06 & 58 & 72 & $45 \%$ & 0.19 \\
\hline
\end{tabular}

\section{DISCUSSION}

This audit reports on the current status of gender representation in Australian public hospital and health service leadership, by describing the gender breakdown of the boards from October to December 2019. Our analysis revealed an equal representation nationally of women board members (53\%) and Chairs (45\%) with some variation by State. These overall results suggest that the Australian healthcare sector is performing well in gender representation on boards. These findings may be partly mediated by the gender differences found in medical and nursing leadership streams, therefore influencing the overall board compositions. Although no health boards included in this study are under federal jurisdiction, the Australian Government is committed to achieving its gender diversity target of women and men each holding at least $40 \%$ of
Government board positions and women holding overall 50\% of Government board positions.[14]

However, regarding the Chair positions, NSW, Western Australia (WA), South Australia (SA) and Queensland (QLD) all have less women than men $13 \%, 20 \%, 30 \%$ and $31 \%$ respectively), with this difference being statistically significant for NSW. Despite the State Governments' commitment to increase representation of women in senior leadership roles in these jurisdictions, gender inequity in health leadership persists. [15-18] In NSW, the significant difference in women in both board (38\%) and Chair roles is consistent with previously documented NSW Government board and committee representation, with women holding only $41.8 \%$ of these positions.[19] If NSW is to reach their target of $50 \%$ of women in senior leadership positions by 2025 , urgent change is required. 
Barriers contributing to this gender inequity may include entrenched and stereotypical attitudes to women, conscious and unconscious bias that limit women's career progression and organisational systems and policies (formal and cultural) that systemically disadvantage women.[20] We encourage health boards in these States to revisit their policies and practices around board membership, ensuring that there is a strategic focus on achieving gender equity. Although NSW, WA, SA and QLD State Governments have established leadership programs to foster leadership skills and improve diversity and representation of women, this has not translated into gender parity in health boards and should be reviewed.

Victoria was the only state where women held significantly more than $50 \%$ of board positions (55\% of board members and $56 \%$ of board Chairs). This year Victoria enacted the Gender Equality Act 2020 to improve workplace gender equality across the public sector.[21] Further, Victorian government policy mandates that no less than $50 \%$ of all new appointments to boards and Chairs be women.[22] This is a successful example of mandated quotas driving change and is likely contributing to our results found across victorian health boards.

This study had several limitations. Importantly, gender was investigated in this study based on photographic appearance, name, and pronoun/title used in the biographic information available online, which may have resulted in some inaccuracies and false assumptions and (inadvertent) exclusion of people with non-binary genders. Concerns were raised about the maintenance of accurate websites for individual organisations; a central transparent government register would assist. There was no available data for Tasmania and the Australian Capital Territory. Furthermore, this study did not address other aspects of diversity including but not limited to one's culture, race, religion, age, sexual orientation or ability, all of which are vital in health leadership. Previous studies have shown that doctors' involvement in hospital governance is associated with better quality management systems and strategic decision making.[23] The authors noted a potential gender imbalance in the occupations of board members, whereby more men board members were doctors whilst women board members were nurses; however this data was not included in this audit and further review of their contribution to health boards would be of value.[24]

The primary role of a health board is to provide good governance, leadership, and overall strategy. The benefits of gender diversity in leadership are well established. $[1,6]$ Demographic diversity, as measured by a matrix of culture, nationality, gender and experience of its directors on boards is associated with improvement on performance in decision making and financial outcomes.[14] Diversity enhances problem solving, increases creativity and raises the level of critical analysis in work groups.[21]

\section{CONCLUSIONS}

Achieving gender balance on boards has been widely recognised as an imperative in the commercial sector[24]but less so in healthcare despite the knowledge that having women in healthcare leadership roles advances healthcare quality, system performance and outcomes. 1 In addition to gender parity on boards, it is essential to ensure representation by those identifying as women in senior leadership roles such as Chair, not only to reduce the gender pay gap but to improve performance across their organisations.[25] Although from this analysis, gender parity has almost been achieved in health leadership boards across Australia, women continue to be under-represented in these senior leadership roles. It is recommended that those States with substantially less Chairs that identify as women employ targeted guidelines, policies and training to encourage, mentor and inspire more diverse leadership in healthcare.

\section{References}

1. Bismark $M$, Morris J, Thomas $L$, et al. Reasons and remedies for under-representation of women in medical leadership roles: a qualitative study from Australia. BMJ Open. 2015;5(1 1):e009384. Published 2015 Nov 16. doi:10.1136/bmjopen-2015-009384.

2. Hempenstall A, Tomlinson J, Bismark M. Gender inequity in medicine and medical leadership. Med J Aust. 2019;21 1 (10):475-475.e1. doi:10.5694/mja2.50388.

3. Just Actions. The female leadership dividend. 2020. Available: <http://justactions.org/just-action/50female-leadership/> (accessed 1/6/20).

4. Victorian Government. The benefits of gender equality. 2019. Available:

https://www.vic.gov.au/benefits-gender-equality (accessed 1/6/20).

5. Beaman L, Duflo E, Pande R, et al. Female leadership raises aspirations and educational attainment for girls: 
a policy experiment in India. Science.

2012;335(6068):582-586. doi:10.1126/science.1212382.

6. Teede H. Advancing women in medical leadership. Med J Aust. 2019;211(9):392-394.el.

doi:10.5694/mja2.50287.

7. Shillcutt S, Parangi S, Diekman S, et al. Survey of Women Physicians' Experience with Elected Leadership Positions. Health Equity. 2019;3(1):162-168. Published 2019 Apr 26. doi:10.1089/heq.2018.0101

8. Ryan M \& Haslam S. The glass cliff: Evidence that women are overrepresented in precarious leadership positions. British Journal of Management 2005; 16:8190.

9. Moss-Racusin C, Dovidio J, Brescoll V, et al. Science faculty's subtle gender biases favor male students. Proc Natl Acad Sci U S A 2012; 1: 16474-16479.

10. Holmes M, O'Connell S, Frey C, et al. Gender imbalance in US geoscience academia. Nature Geosci 2008; 1: 79-82.

11. Australian Medical Association. The AMA Gender Equity Summit Report. 2019. Available:

https://ama.com.au/sites/default/files/documents/A MA\%20GES\%20Report\%20Aug\%202019_2.pdf (accessed 1/6/20).

12. Madsen S, Townsend A, \& Scribner R. Strategies That Male Allies Use to Advance Women in the Workplace. The Journal of Men's Studies 2019; https://doi.org/10.1177/1060826519883239.

13. Male Champions of Change. Practical Actions to Accelerate Change on Gender Equity. 2019.

Available:

https://malechampionsofchange.com/reports-andresources/ (accessed 1/6/20).

14. Australian Government. Gender Balance on Australian Government Boards. 2019. Available:

https://www.pmc.gov.au/officewomen/leadership/gender-balance-australiangovernment-boards (accessed 1/6/20).

15. Government of South Australia. Gender Equality in Leadership in the Public Sector. 2020. Available: https://officeforwomen.sa.gov.au/womenspolicy/womens-leadership/gender-equality-inleadership-in-the-public-sector (accessed 1/6/20).

16. Government of Western Australia. Building a Strong Western Australia Through Gender Equity. 2020.

Available: https://www.dtwd.wa.gov.au/whats- new/building-a-stronger-western-australia-throughgender-equity (accessed 1/6/20).

17. Queensland Government. Gender Equity. 2019. Available: https://www.forgov.qld.gov.au/genderequity (accessed 1/6/20).

18. New South Wales Government. NSW 2018 Annual Report. 2018. Available:

https://www.women.nsw.gov.au/download? file=6473 91 (accessed 1/6/20).

19. New South Wales Government. Women in Leadership. 2020. Available:

http://www.healthshare.nsw.gov.au/careers/womenin-leadership (accessed 1/6/20).

20. Deloite Access Economics. Research Report Toward Gender Parity: Women On Boards Initiative Department of Communities, Child Safety and Disability Services, Office for Women. 2016. Available: https://www2.deloitte.com/content/dam/Deloitte/au LDocuments/Economics/deloitte-au-toward-genderparity-women-on-boards-initiative-041016.pdf (accessed 16/02/21).

21. Victorian Government. Gender Equality Act. 2020. Available: https://www.vic.gov.au/gender-equality-bill (accessed 1/6/20).

22. Victorian Government. Appointment and Remuneration Guidelines. 2019. Available: https://www.vic.gov.au/guidelines-appointmentremuneration (accessed 1/6/20).

23. Walid B, Claude F, Taieb H, et al. What Makes Better Boards? A Closer Look at Diversity and Ownership. British Journal of Management 2013; 24: 85-101.

24. Rotar A, Botje D, Klazinga N, et al. The involvement of medical doctors in hospital governance and implications for quality management: a quick scan in 19 and an in depth study in 7 OECD countries. BMC Health Serv Res. 2016;16 Suppl 2(Suppl 2):160. Published 2016 May 24.doi:10.1186/s12913-016-1396-4.

25. Workplace Gender Equality Agency. Gender Equity Insights 2020 Delivering The Business Outcomes. 2020. Available:

https://www.wgea.gov.au/sites/default/files/docume nts/BCEC\%20WGEA\%20Gender\%20Equity\%20lnsights\% 202020\%20Delivering\%20the\%20Business\%200utcomes _WEB_FINAL.pdf (accessed 1/6/20). 